\title{
Treatment efficacy on the cognitive competence of convicted intimate partner violence offenders
}

\author{
Esther Arias ${ }^{1}$, Ramón Arce ${ }^{1 *}$, María J. Vázquez ${ }^{2}$, and Verónica Marcos ${ }^{1}$ \\ 1 Universidad de Santiago de Compostela (Spain) \\ 2 Universidad de Vigo (Spain)
}

\begin{abstract}
Título: Eficacia del tratamiento en la competencia cognitiva en sentenciados por violencia de género.

Resumen: La evaluación de la eficacia del tratamiento de maltratadores en los Registros Oficiales o los Informes de las parejas no es válida, al tiempo que las intervenciones eficaces se dirigen a dotarlos de competencia cognitiva y conductual. Por ello diseñamos un estudio de campo para medir los efectos de la intervención en la competencia cognitiva. Un total de 100 condenados por violencia de género que completaron un programa penitenciario de tratamiento en la comunidad fueron evaluados pre- y posttratamiento en la competencia cognitiva, esto es, auto-concepto, inteligencia emocional, atribución de responsabilidad, destrezas cognitivas para el afrontamiento de eventos estresantes en pareja, expresión y control de la ira, y creencias irracionales y pensamientos distorsionados. Los resultados mostraron un efecto significativo del tratamiento en la adquisición de las destrezas cognitivas. Sucintamente, el tratamiento potenció el autoconcepto general el $18.2 \%$ y las dimensiones internas del auto-concepto auto-satisfacción el $33.5 \%$ y comportamiento el $25.6 \%$; y la claridad para discriminar las emociones el $31.8 \%$. Además, el tratamiento incrementó la asunción interna de responsabilidad el $31.8 \%$; el control de la ira el 19.1\%; y el uso de estrategias adaptativas para el afrontamiento de eventos estresantes en pareja entre el $48.9 \%$ y el $61.3 \%$. Finalmente, el tratamiento redujo el uso de estrategias desadaptativas entre el $25.6 \%$ y el $35.1 \%$; y las creencias irracionales y pensamientos distorsionados relacionados con el uso de la violencia, rol de género y dependencia emocional, en el 78.2\%, $48.2 \%$ y $63.6 \%$, respectivamente. No obstante, no todos los maltratadores se beneficiaron del tratamiento.

Palabras clave: Maltratador; Intervención en la comunidad; Competencia cognitiva; Evaluación de programas; Destrezas cognitivas.
\end{abstract}

\section{Introduction}

Since the 1974 doctrine heralding Nothing works in the rehabilitation of criminal offenders in Martinson's meta-analytical review that found no positive intervention effects, substantial progress has been made in the treatment of criminal offenders. These have been underpinned by models of additive and accumulative deficits, needs or weakness aimed at identifying specific deficiencies of each delinquent to design a bespoke treatment program targeting the rehabilitation of the criminal offender's deficits, needs or weaknesses (Arce, Arias, Novo, \& Fariña, 2020; Carbajosa, Catalá-Miñaña, Lila, \& Gracia, 2017; Gannon, Olver, Mallion, \& James, 2019; Redondo, Sánchez-Meca, \& Garrido, 2002). Psychosocial treatment has been the primary intervention type, particularly cognitive-behavioural treatment programs, which has proven to be the most effective intervention program for general delinquency (Gannon et al., 2019; Redondo et al.,

* Correspondence address [Dirección para correspondencia]: Ramón Arce. Facultad de Psicología. Campus Vida, s/n. 15782 Santiago de Compostela (Spain). E-mail: ramon.arce@,usc.es

(Article received: 20-05-2020; revised: 26-05-2020; accepted: 12-06-2020)
Abstract: The evaluation of the efficacy of treatment of batterers in Official or Couple Records is not valid, whilst the efficient interventions are focused on the empowerment of cognitive and behavioural competence. A field study for measuring the effects of the treatment on the cognitive competence was designed. A total of 100 batterers who had completed a community penitentiary intervention programme, were assessed pre- and post-treatment in cognitive competence i.e., self-concept, emotional intelligence, attribution of responsivity, cognitive skills to cope intimate-partnerrelated stressful events, expression and control of anger, and irrational beliefs and distorted thoughts. The results showed a significant effect of the treatment in the acquisition of cognitive competence skills. Succinctly, treatment empowered the general self-concept in $18.2 \%$, and the internal dimensions of self-concept self-satisfaction in $33.5 \%$ and behaviour in $25.6 \%$; and clarity to discriminate among moods in $31.8 \%$. Moreover, treatment increased the assumption of internal responsivity in $31.8 \%$; anger control in 19.1\%; and the use of adaptive strategies to cope intimatepartner-related stressful events between $48.9 \%$ and $61.3 \%$. Finally, treatment involved a fall in the use of maladaptive strategies to cope intimatepartner-related stressful events between $25.6 \%$ and $35.1 \%$; and in the irrational beliefs and distorted thoughts related with the use of violence, in $78.2 \%, 48.2 \%$ y $63.6 \%$, for use of violence, gender roles and emotional dependence, respectively. Nonetheless, not all the batterers benefited from treatment

Keywords: Batterer; Community intervention; Cognitive competence; Programme evaluation; Cognitive skills.
2002), and for specific crime typologies such as sexual (Schmucker \& Lösel, 2015), and IPV offenders (Arce et al., 2020). Interventions are grounded on a multimodal intervention models focusing on cognition and behaviour that can be modified or eradicated (dynamic factors). Thus, successful interventions should target cognitive and behavioural competence to address specific needs of each offender (RomeroMartínez, Lila, Martínez, Pedrón-Rico, \& Moya-Albiol, 2016). These needs have been classified by Bonta and Andrews (2017) according to criminogenic (e.g., antisocial cognitions), having a direct incidence on recidivism, and noncriminogenic needs (e.g., self-esteem), having no direct incidence on the recidivism rate, only the former being the target of intervention programs. Nevertheless, claims that noncriminogenic needs are related to recidivism have been substantiated, and a deficiency in these needs is characteristic of the delinquent population (Basanta, Fariña, \& Arce 2018; Lila, Martín-Fernández, Gracia, López-Ossorio, \& González, 2019; Maruna, 2004). Thus, deficiencies in noncriminogenic needs act as facilitators of recidivism, and should be targeted as protective factors (Basanta et al., 2018; Romero-Martínez, Lila, Gracia, \& Moya-Albiol, 2019), ensuring interventions 
address the specific needs of each offender (Lila, Gracia, \& Catalá-Miñana, 2018).

Convicted IPV offenders are among the prison population with the worst prognosis in rehabilitation and social reintegration. These offenders are driven by internal, stable, and global cognitions, known as toxic cognitions that are highly refractory to intervention (Maruna, 2004). Thus, in terms of recidivism, treatment of batterers is among the least efficacy (Arce et al., 2020; Arias, Arce, \& Vilariño, 2013; Babcock, Green, \& Robie, 2004) as IPV offenders are not susceptible to spontaneous retraction (Martín, Padrón, \& Redondo, 2019). Moreover, the efficacy of interventions according to Official Records (ORs) ranged from 5\% (Babcock et al., 2004) to $20 \%$ (Arias et al., 2013), whereas as in Couple Reports (CRs) it was null (Arce et al., 2020). The efficacy of interventions on recidivism measured in ORs was invalid as it artificially increased the efficacy of the interventions. Furthermore, measures of efficacy derived from CRs are unreliable and invalid as not all couples cooperate with evaluations, which are contaminated by the tendency of current couples to conceal or trivialize victimization (Lila, Oliver, Catalá-Miñaña, Galiana, \& Gracia, 2014), as do IPV offenders (Weber, Taylor, Cantos, Amado, \& O'Leary, 2019). Regardless, the fundamental aim of treatment is to address the needs of IPV offenders by intervening in their cognition and behaviour. Thus, cognition should be the target of the interventions.

The most recurrent cognitive needs in delinquency in general, and IPV in particular are as follows: poor copping skills in dealing with intimate-partner-related stressful events (Arce \& Fariña, 2010); refusing to accept responsibility for IPV (Martín-Fernández et al., 2018); low self-concept, mainly cognitive that aggravates vulnerability (Arce, Fariña, \& Novo, 2014); cognitive deficiencies in managing and regulating emotions in a mutual relationship (Fernández-Suárez, Pérez, Herrero, Juarros-Basterretxea, \& Rodríguez-Díaz, 2018); anger management (Loinaz, Marzabal, \& Andrés-Pueyo, 2018), and cognitive distortions regarding gender (Brazão, Rijo, Salvador, \& Pinto-Gouveia, 2017; Ramiro-Sánchez, Ramiro, Bermúdez, \& Buela-Casal, 2018).

Bearing this context in mind, a field study was performed to assess the effects of community IPV offender rehabilitation programs designed to identify and address the dynamic cognitive needs of IPV offenders (cognitions), that are modifiable, and the primary purpose of treatment.

\section{Method}

\section{Participants}

A total of 100 IPV first-offenders serving community orders, age range 23 to 66 years $(M=38.83, S D=9.97)$, participated in the study. The nationality of most offenders was Spanish (94\%). As for academic status, $70 \%$ had primary, $24 \%$ secondary, and $6 \%$ university education. In terms of occupation, $70 \%$ were employed, $19 \%$ unemployed, and the remainder in other contingencies such as retirement, sick leave, etc. All of the participants completed the Programa Galicia de Reeducación para Maltratadores de Género [Galician Programme for the Treatment and Re-Education of Convicted Gender Aggressors] (Arce \& Fariña, 2006, 2010; Arce, Fariña, Vázquez, Novo, \& Seijo, 2015a, 2015b) in compliance with their community sentence.

\section{Procedure and design}

The IPV offenders were remitted by the courts to the Galicia Gender Offenders Reeducation Program in compliance with community sentences. Prior to intervention, all IPV offenders were informed of the treatment and signed their voluntary participation. IPV offenders refusing to participate in the 2 to 5 -year program were remitted back to the courts to be incarcerated (under 2 years). After signing the pledge to participate, individual needs analysis was undertaken (pre-intervention evaluation), to design an intervention program adjusted to the specific needs of each participant, and to follow-up implementation by revaluating the effects of the intervention (post-intervention evaluation). The instruments were applied by experienced and trained psychologists of the program in individual sessions.

\section{The Galician Re-Education Programme for Male In- timate-Partner Violent Offenders}

The Galician Re-Education Programme for Male Intimate-Partner Violence Offenders (Arce \& Fariña, 2006, 2010), a community intervention program, based on a multimodal approach i.e., targeted to cognitions and behaviours, assumes batterers have cognitive needs which should be the target of rehabilitation. Complementarily, the intervention programme is fitted to the specific needs of each batterer. The most distinctive feature of the rehabilitation programme was the control of programme compliance and the offender's progress. The contents of the programme were in accordance with the current Spanish legislation i.e., the programme begins with offenders being informed of the regulations and their obligations; the offenders acceptance and signing of the rehabilitation programme; assessment of the offender's needs and deficits in order to adjust programme implementation; followed by the admission of the facts and accepting responsibility, which is the first step towards rehabilitation of all offenders. Moreover, the programme included a gender equality perspective. The remaining contents were adjusted and sequenced to the specific needs of each batterer (for a full review of contents see Arce et al., 2015a, 2015b). Each phase of the intervention programme was administered in two sessions: one-to-one sessions for cognitive interventions, and group sessions for rehearsing non-violent behaviour. Progress of a session to the next was only after the acquisition of the skills was verified in all the group members. 


\section{Measurement instruments}

Cognitive self-concept was evaluated using the Tennessee Self Concept Scale-Second Edition [TSCS-2] (Fitts \& Warren 1996) consisting of 90 items that are responded on a 5-point Likert-type scale. A general measure of the selfconcept and three internal (i.e., cognitive) measures (Identity, Self-Satisfaction and Behaviour) were taken. A back translation procedure was followed to translate the scale to Spanish that was reliable for the sample of offenders (Arce et al., 2014) in the General Self-Concept $(\alpha=.87)$, Identity $(\alpha=.81)$, SelfSatisfaction $(\alpha=.79)$ and Behaviour $(\alpha=.82)$.

The Spanish modified version of the Trait Meta-Mood Scale [TMMS] (Fernández-Berrocal, Extremera, \& Ramos, 2004) was administered to evaluate emotional intelligence. The scale measures three dimensions underpinning emotional intelligence: Attention (perceived ability to attend to moods and emotions), Clarity (perceived ability to discriminate among moods), and Repair (perceived ability to regulate moods). Test-retest (4 weeks) correlation obtained was of .60 for Attention, .70 for Clarity, and .83 for Repair.

As for measuring the attributional styles, the Spanish translation of the Rotter Locus of Management Scale was employed (Ferrando, Demestre, Anguiano-Carrasco, \& Chico, 2008). High scores ascribe attribution to an external locus of control (e.g., destiny, luck) or beyond their control, whereas low scores are indicative of internal locus of control where the expected outcomes are product of their own behaviour and personal characteristics. The adapted version is of proven reliability $(\alpha=.72)$ and validity.

As for the measure of coping skills, the Spanish adaptation of the Coping Responses Inventory Adult Form [CRIA] was applied (Kirchner, Forns, Muñoz, \& Pereda, 2008). Respondents were required to answer 48 items on how they coped with intimate-partner-related stressful events on a 4point scale (from not at all to fairly often). The instrument assesses eight different types of coping responses to stressful life circumstances: Logical analysis (for males: $\alpha=.55$ ), Positive reappraisal $(\alpha=.64)$, Seeking guidance and support $(\alpha=$ $.52)$, Problem solving $(\alpha=.70)$, Cognitive avoidance $(\alpha=$ $.58)$, Acceptance or resignation $(\alpha=.61)$, Seeking alternative rewards $(\alpha=.59)$, and Emotional discharge $(\alpha=.60)$.

Anger management was assessed with the Anger Expression Index (AEI) of the Spanish adaptation of the Staxi-2 (Miguel-Tobal, Casado, Cano-Vindel, \& Spielberger, 2001). This index is an overall measure of total anger expression: high scores indicate expressions of anger (aggressive thoughts, language, and behaviour), whilst low scores indicate anger management. The stability (test-retest) of this index has been reported to be .70 with an internal consistency (cronbach's alpha) of .64.

Gender related cognitive distortions were evaluated with the Cuestionario de Creencias Irracionales y Pensamientos Distorsionados [Irrational Beliefs and Distorted Thoughts Questionnaire] (Arce \& Fariña, 2005). The questionnaire, that is answered on a five-point Likert scale (from totally disa- gree to totally agree), is structured in three dimensions: 1$)$ use of violence $(\alpha=.86) ; 2)$ gender roles (i.e., the role of women in the couple and in other areas of life) $(\alpha=.82)$; and 3) emotional dependence (dominant emotional dependence) $(\alpha=$ .74). The global reliability for the scale was .92 .

\section{Data analysis}

A quasi-experimental design was used to compare the means of repeated-measures t-tests, ANOVAS, and MANOVAS for two conditions (pre-treatment evaluation vs. post-treatment evaluation). In the multivariate $F$, if the assumption of sphericity was violated, the GreenhouseGeisser correction was used as it is robust to the violation of this assumption (no contingency occurred in any of the comparisons). As the effect sizes of the multivariate tests were estimated as $\eta_{\mathrm{p}}^{2}$ or $d$, and the magnitude was interpreted in terms of the probability of superiority of the effect size in relation to all possible $\left(\mathrm{PS}_{\mathrm{ES}}\right.$; Monteiro, Vázquez, Seijo, \& Arce, 2018). The quantification of treatment effects was obtained using the BESD (Redondo, Fariña, Seijo, Novo, \& Arce, 2019).

The analysis of the differences in means was insufficient and had to be complemented with case studies. Thus, to determine the minimum treatment effects, the lower limit $90 \%$ of the distribution of the sample was calculated, so that $95 \%$ past the limit (clinical significance); and from 1-U3 to calculate the percentage of post-treatment offenders failing to reach the mean of the pre-treatment distribution (Redondo et al., 2019).

\section{Ethical Considerations}

The data was stored and processed in accordance with the Spanish Data Protection Law (Ley Orgánica 3/2018, de 5 de diciembre, de Protección de Datos Personales y Garantía de los Derechos Digitales) and guaranteeing the rights of convicted provided by the Spanish General Penitentiary Law (Ley Orgánica 1/1979, de 26 de septiembre, General Penitenciaria).

\section{Results}

\section{Self-Concept}

The results showed a significant improvement, $t(99)=$ 3.61, $p<.001$, in General Self-Concept for the treatment factor $\left(M_{\text {pre }}=358.95\right.$ vs. $\left.M_{\text {post }}=372.13\right)$. The effect size, $d=$ 0.37 , of treatment was above $20.5 \%$ of all possible that reinforce self-concept $\left(\mathrm{PS}_{\mathrm{SE}}=.205\right)$. The development of SelfConcept was quantified as a result of the intervention in $18.2 \%(r=.182)$. However, $35.6 \%$ of treated offenders failed to reach the average pre-treatment distribution $(1-\mathrm{U} 3=.356)$ and the lower limit of the distribution of 302.19 (LL 90\% CI $=302.19)$. In other words, almost $36 \%$ of treated offenders 
failed to sufficiently benefit from the intervention, and there was considerable margin for improvement.

Moreover, cognitive components of self-concept were mediated by the treatment factor (pre- vs. post-treatment), $F(3,97)=4.30, p<.01,1-\beta=.853$, explaining $11.7 \%, \eta_{p}{ }^{2}=$ .117 , of the variance, un effect size higher than $69.5 \%$ of all possible $\left(\mathrm{PS}_{\mathrm{ES}}=.695\right)$. The univariate effects (see Table 1) showed a significant improvement in Self-Satisfaction and Behaviour. This indicated a recovery of Self-Satisfaction of
$33.5 \%(r=.335)$, and Behaviour of $25.6 \%(r=.256)$. However, $23.9 \%(1-\mathrm{U} 3=.239)$ and $29.8 \%(1-\mathrm{U} 3=.298)$ of participants failed to reach the average pre-treatment distribution in self-satisfaction behaviour, respectively; and the lower limit of the distribution was 94.17 (LL 90\% CI = 94.17), and 95.95 (LL 90\% CI= 95.95). In other words, the intervention was not sufficiently beneficial for around $24 \%$ to $30 \%$ of those treated, while for most the improvement was significant and substantial.

Table 1. Univariate Effects on Self-Concept for the Treatment Factor. Within-subjects Effects.

\begin{tabular}{lcccccccc}
\multicolumn{1}{l}{ Table 1. Univariate Effects on Self-Concept for the Treatment Factor. Within-subjects Effects. } \\
\hline Variable & $F$ & $p$ & $d$ & $1-\beta$ & $M_{\text {pre }}$ & $M_{\text {post }}$ & $1-\mathrm{U3}$ & LL 90\% CI \\
\hline Identity & 3.13 & .080 & 0.36 & .418 & 124.40 & 126.47 & ----- \\
Self--Satisfactio & 12.50 & .001 & 0.71 & .938 & 115.84 & 121.44 & .239 \\
Behavior & 7.04 & .009 & 0.53 & .748 & 118.75 & 122.67 & .298 \\
\hline
\end{tabular}

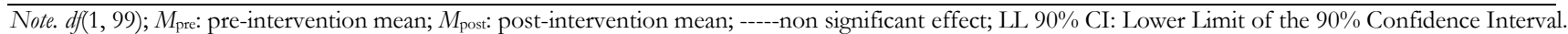

\section{Emotional intelligence}

The results of the MANOVA showed a significant multivariate effect for the treatment factor (pre- vs. posttreatment) in emotional intelligence, $F(3,97)=4.35, p<.01$, $1-\beta=.857$, with treatment explaining $11.8 \%$ of the variance, $\eta_{\mathrm{p}}{ }^{2}=.118$, an effect larger than $69.9 \%$ of all possible effects $\left(\mathrm{PS}_{\mathrm{ES}}=.699\right)$.

The results of the univariate effects (see Table 2) revealed IPV offenders increased competence in the Clarity dimension following treatment. An effect higher than $36.2 \%$ was observed in all of the interventions with positive effects, accounting for a $31.8 \%$ increase $(r=.318)$. Though no significant treatment effect was observed in the Attention dimension, the effect size was from small to moderate, with a notable improvement in perceived ability to attend to moods and emotions of $15.8 \%(r=.158)$. In any case, the pretreatment average for the Attention competence ranged from 22 to 32. No treatment effect was found in the Repair dimension. Nonetheless, the offender population under treatment was in the region of normality in this dimension of pre-treatment (26 to 35$)$.

Table 2. Univariate Effects on the Emotional Intelligence for the Treatment Factor. Within-subjects Effects.

\begin{tabular}{lcccccccc}
\hline Variable & $F$ & $p$ & $d$ & $1-\beta$ & $M_{\text {pre }}$ & $M_{\text {post }}$ & 1-U3 \\
\hline Clarity & 11.43 & .001 & 0.67 & .92 & 30.22 & 32.69 & .252 & LL 90\% CI \\
Attention & 2.52 & .116 & 0.32 & .35 & 28.49 & 29.62 & ----- & 20.00 \\
Repair & 0.01 & .953 & 0.00 & .05 & 26.47 & 26.44 & ----- & ---- \\
\hline
\end{tabular}

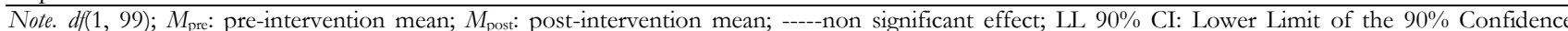
Interval.

\section{Locus of control}

The results of the treatment effect on attributive processes showed a significant effect, $t(99)=6.19, p<.001$, with a correction towards an acceptance of internal responsibility $\left(M_{\text {pre }}=8.36\right.$ vs. $\left.M_{\text {post }}=6.14\right)$. The effect size of treatment, $d=0.67$, was greater than $36.2 \%$ of possible effects that corrected towards attributing to internal responsibility $\left(\mathrm{PS}_{\mathrm{ES}}=.362\right)$. The tendency to attribute an internal locus of control increased $31.8 \%(r=.318)$ after the intervention. However, $25.2 \%$ of treated IPV offenders failed to reach the average pre-treatment distribution $(1-\mathrm{U} 3=.252)$ and the lower limit of the distribution was 302.19 (in this measure it was the upper limit as the measure was the inverse; $\mathrm{UL}$ 90\% CI = 302.19). That is, the intervention was not sufficiently beneficial for nearly $36 \%$, with a significant margin for improvement.

\section{Cognitive skills for coping with intimate-partner- related stressful events}

A MANOVA was performed on the impact of the treatment factor on copping strategies, the results found a significant multivariate effect, $F(8,92)=13.72, p<.001,1-\beta$ $=1.00$, explaining $54.4 \%$ of the variance, $\eta_{\mathrm{p}}^{2}=.544$, an effect larger than $93.8 \%$ of all possible effects $\left(\mathrm{PS}_{\mathrm{ES}}=.938\right)$.

The results of the univariate effects (see Table 3 ) revealed significant and positive effects (an increase in the use of the strategies) of treatment on 'Logical analysis', Positive reappraisal, 'Seeking guidance and support', 'Problem solving', and 'Seeking alternative rewards' strategies. In contrast, treatment had significant negative effects on 'Cognitive avoidance', and 'Acceptance or resignation' strategies. Succinctly, post-treatment IPV offenders increased their cognitive-approach response by applying coping strategies in intimate-partner-related stressful events: 'Logical analysis' (cognitive attempts to understand and prepare mentally for a stressor and its consequences) of 48.9\% $(r=.489)$, and 
'Positive reappraisal' (cognitive attempts to construe and restructure a problem in a positive way while still accepting the reality of the situation) of $50.5 \%(r=.505)$, with a reduction in 'Cognitive-avoidance' (cognitive attempts to avoid thinking realistically about a problem) of $25.6 \%(r=.256)$, and 'Acceptance or resignation' (cognitive attempts to react to the problem by accepting it) of $35.1 \%(r=.351)$.

Moreover, treatment increased behavioural coping responses for IPV events by 55.9\% $(r=.559), 61.3 \%(r=$ $.613)$, and $54.5 \%(r=.545)$ for 'Seeking guidance and sup- port' (behavioural attempts to seek information, guidance, or support), 'Problem solving' (behavioural attempts to take action to deal directly with the problem), and 'Seeking alternative rewards'(behavioural attempts to get involved in substitute activities and create new sources of satisfaction), respectively.

The intervention was ineffective in a small percentage of treated offenders (see 1-U3 in Table 3), that is, the margin for improvement of treatment was small.

Table 3. Univariate Effects on Coping Responses to an Intimate-Partner-Related Stressful Event for the Treatment Factor. Within-subjects Effects.

\begin{tabular}{lcccccccc}
\hline Variable & $F$ & $p$ & $D$ & $1-\beta$ & $M_{\text {pre }}$ & $M_{\text {post }}$ & $1-\mathrm{U} 3$ & LL $90 \%$ CI \\
\hline Logical analysis & 32.79 & .000 & 1.15 & 1.00 & 7.81 & 10.62 & .126 & 2.68 \\
Positive reappraisal & 33.99 & .000 & 1.17 & 1.00 & 9.45 & 12.69 & .121 & 2.32 \\
Seeking guidance and support & 44.92 & .000 & 1.35 & 1.00 & 6.71 & 9.48 & .089 & 2.15 \\
Problem solving & 59.73 & .000 & 1.55 & 1.00 & 9.71 & 13.57 & .061 & 5.65 \\
Cognitive avoidance & 6.98 & .010 & -0.53 & .744 & 8.84 & 7.49 & .298 & $15.79+$ \\
Acceptance or resignation & 14.10 & .000 & -0.75 & .961 & 7.99 & 6.18 & .227 & $13.00+$ \\
Seeking alternative rewards & 41.79 & .000 & 1.30 & 1.00 & 7.33 & 10.70 & .097 & 2.86 \\
Emotional discharge & 0.70 & .406 & -0.17 & .131 & 5.12 & 4.82 & ----- & ---- \\
\hline
\end{tabular}

Note. $d f(1,99) ; M_{\text {pre: }}$ pre-intervention mean; $M_{\text {post: }}$ post-intervention mean; -----non significant effect; LL $90 \%$ CI : Lower Limit of the $90 \%$ Confidence Interval.; + Upper Limit of of the $90 \%$ Confidence Interval (inversely measured variable).

\section{Anger expression and management}

The results of treatment effects on the Anger Expression Index (AEI) revealed treatment significantly empowered, $t(99)=3.73, p<.001$, anger management $\left(M_{\text {pre }}=36.3 \mathrm{vs}\right.$. $\left.M_{\text {post }}=33.1\right)$. The effect size of treatment, $d=0.39$, was higher than $21.3 \%$ of all possible $\left(\mathrm{PS}_{\mathrm{ES}}=.213\right.$ ) improving post-intervention anger management with a $19.1 \%(r=$ .191). However, $34.9 \%$ post-treatment IPV offenders failed to reach the pre-treatment distribution average $(1-\mathrm{U} 3=.349)$ and the lower limit of the distribution was 302.19 (in this measure it was the upper limit as the measure was the inverse; UL $90 \% \mathrm{CI}=16.99$ ). In other words, almost $35 \%$ of treated offenders did not benefit sufficiently from the intervention with a significant margin for improvement.

\section{Irrational beliefs and distorted thoughts}

The results of the MANOVA showed a significant multivariate effect for the treatment factor (pre- vs. post- treatment), $F(3,97)=54.42, p<.01,1-\beta=1.0$, with treatment explaining $62.7 \%, \eta_{\mathrm{p}}{ }^{2}=.627$, of the variance, an effect larger than $79.2 \%$ of all possible effects $\left(\mathrm{PS}_{\mathrm{ES}}=.792\right)$.

The univariate effects (see Table 4) found a significant reduction in cognitive distortions in relation to the 'Use of violence', 'Gender roles', and 'Emotional dependence'. In short, distorted attitudes and beliefs declined for violence $78.2 \%(r=.782)$; gender roles $48.2 \%(r=.482)$; and emotional dependency $63.6 \%(r=.636)$. The magnitude of the effect was greater than $92.3 \%$ of all possible $\left(\mathrm{PS}_{\mathrm{ES}}=.923\right)$; $56.5 \%$ for gender roles $\left(\mathrm{PS}_{\mathrm{ES}}=.565\right)$; and $75.8 \%$ for emotional dependency $\left(\mathrm{PS}_{\mathrm{ES}}=.758\right)$. The intervention was ineffective for a small percentage of treated offenders (see 1-U3 in Table 4), but the margin for improvement of treatment was very high (by comparison of the Upper Limit of the Confidence Interval in Table 4 with the pre-intervention mean).

Table 4. Univariate Effects on the Irrational Beliefs and Distorted Thoughts for the Treatment Factor. Within-subjects Effects.

\begin{tabular}{lcccccccc} 
Variable & $F$ & $p$ & $D$ & $1-\beta$ & $M_{\text {pre }}$ & $M_{\text {post }}$ & $1-\mathrm{U} 3$ & UL 90\%CI \\
\hline Use of Violence & 156.36 & .000 & 2.51 & 1.00 & 20.35 & 9.26 & .006 & 21.96 \\
Gender role & 29.73 & .000 & 1.10 & 1.00 & 9.75 & 5.44 & .136 & 13.75 \\
Emotional Dependence & 67.10 & .000 & 1.65 & 1.00 & 13.56 & 7.18 & .050 & 15.65 \\
\hline
\end{tabular}

Note. $d f(1,99) ; M_{\text {pre: }}$ pre-intervention mean; $M_{\text {post: }}$ post-intervention mean; UL $90 \%$ CI: Upper Limit of the $90 \%$ Confidence Interval.

\section{Discussion}

Prior to discussing the results, several limitations of this study should be borne in mind. First, the results are not generalizable to other treatments as they are constrained to a specific intervention program (the context effect). Second, the psychologists applying treatments influence the magnitude of the results, so variability was due this factor (Gannon et al., 2019). Third, the specific limitations of the measurement instruments employed (lack of reliability and/or validity), indicate that part of the variance may be due to the measurement instrument and not the measure itself (Pod- 
sakoff, MacKenzie, Lee, \& Podsakoff, 2003). Fourth, the response of this population is biased in an attempt to either conceal negative characteristics (Arce, Fariña, Seijo, \& Novo, 2015), or to adopt positive ones, particularly in cognitive distortions (Fariña, Redondo, Seijo, Novo, \& Arce, 2017). Fifth, though the treatment program included techniques for generalizing acquired skills and strategies for coping with reallife IPV context, this transference was not evaluated. Taking into account these limitations, the results revealed the following:

a) Treatment modified the cognition of IPV offenders by developing cognitive competence (in turn social competence) for coping with intimate-partner-related stressful events.

b) In general, the effects on self-concept were significant and of a large magnitude with a large margin for improvement.

c) Treatment contributed to an overall reinforcement of self-concept, which is a good predictor of resistance to recidivism (Finkenauer et al., 2015). Moreover, treatment reinforced the cognitive aspects of Self-Satisfaction (how I fell about myself) and Behaviour (what I do or how I act), but not Identity (what I am).

d) As for the management and control of emotions, treatment improved competence in understanding and discriminating between emotions, but not attention to emotions and repairing emotions, though these were within pre-treatment normality region. That is, treatment developed cognitive competence in calculating the probability of exercising violent behaviour (Brackett, Rivers, \& Salovey, 2011).

e) Moreover, treatment empowered anger management, and had a combined effect with effective management of anger generating emotions on reducing IPV (Foran \& O'Leary, 2008).

f) Likewise, treatment corrected attribution of responsibility towards internal attribution (Martín-Fernández, Gracia y Lila, 2018; Martín-Fernández, Gracia, Marco et al., 2018). Self-attribution of responsibility in IPV is crucial for treatment to be effective in preventing recidivisms (Carbajosa, Catalá-Miñana, Lila, Gracia, \& Boira, 2017).

\section{References}

Arce, R., Arias, E., Novo, \& Fariña, F. (2020). Are interventions with batterers effective? A meta-analytical review. Psychosocial Intervention. Advance online publication. https://doi.org/10.5093/pi2020a11

Arce, R., \& Fariña, F. (2005). Cuestionario de Creencias Irracionales y Pensamientos Distorsionados sobre el empleo de la violencia, los roles de género y la relación de pareja. Santiago de Compostela, Spain: Unidad de Psicología Forense.

Arce, R., \& Fariña, F. (2006). Programa Galicia de Reeducación para Maltratadores de Género [Galician Programme for the Treatment and Re-education of Convicted Gender Aggressors]. Anuario de Psicología Jurídica, 16, 41-64. Retrieved from https://journals.copmadrid.org/apj/archivos/102982.pdf

Arce, R., \& Fariña, F. (2010). Diseño e implementación del Programa Galicia de Reeducación de Maltratadores: Una respuesta psicosocial a una necesidad social y penitenciaria [Design and implementation of the Galician Program for Batterers Re-education: A psychosocial answer to g) The improvement in coping strategies for intimatepartner-related stressful events was the highest possible (the effect was greater than $92 \%$ of all possible). Furthermore, in line with the classification of Arce, Seijo, Fariña, \& Mohamed-Mohand (2010) of the functionality of skills and strategies for coping with stressful events, treatment promoted the employment of adaptive strategies fostering prosocial behaviour (logical analysis, positive re-evaluation, search of guidance and support, problem-solving, and the search for alternative activities); and stifled maladaptive strategies motivating violent behaviour (cognitive evasion, acceptance, or resignation).

h) Moreover, treatment had considerably large effects, larger than $79.2 \%$ of all possible effects, on the management of cognitive distortions. Thus, offenders were left without any attitudinal and cognitive rationale for IPV. That is, violence towards a partner (mostly women) would involve cognitive contradictions owing to the lack of cognitive support for the use of violence.

i) Finally, the combined effects of cognitive competence in the management and control of emotions, and of anger management skills and strategies for coping with intimate-partner-related stressful events (mainly involving violence against women) may not be additive, but multipliable, or exponential.

Nevertheless, the margin for improvement of treatment failure was considerable in general self-concept, selfsatisfaction, behaviour, attributional processes, clarity in emotional perception, and anger management, given that around one-fourth to a third of post-treated offenders did not benefit sufficiently from the intervention (failed to reach the pre-intervention distribution average). But, the margin for failure in the management of cognitive distortions and the acquisition of adaptive skills reducing the use of maladaptive strategies was almost negligible (.05).

Funding: This research has been sponsored by a grant of the Spanish Ministry of Economy, Industry and Competitiveness (PSI2017-87278-R). a social and penitentiary need]. Psychosocial Intervention, 19(2), 153-166. https://doi.org/10.5093/in2010v19n2a7

Arce, R., Fariña, F., \& Novo, M. (2014). Competencia cognitiva en penados primarios y reincidentes: Implicaciones para la reeducación [Cognitive competence among recidivist and non-recidivist prisoners: Implications for the rehabilitation]. Anales de Psicologia, 30(1), 259-266. http://dx.doi.org/10.6018/analesps.30.1.158201

Arce, R., Fariña, F., Seijo, D., \& Novo, M. (2015). Assessing impression management with the MMPI-2 in child custody litigation. Assessment, 22(6), 769-777. http://dx.doi.org/10.1177/1073191114558111

Arce, R., Fariña, F., Vázquez, M. J., Novo, M., \& Seijo, D. (2015a). Programa Galicia de reeducación de agresores de género: Manual de intervención (Vol. I). Santiago de Compostela, Spain: Andavira.

Arce, R., Fariña, F., Vázquez, M. J., Novo, M., \& Seijo, D. (2015b). Programa Galicia de reeducación de agresores de género: Manual de intervención (Vol. II). 
Santiago de Compostela, Spain: Andavira.

Arce, R., Seijo, D., Fariña, F., \& Mohamed-Mohand, L. (2010). Comportamiento antisocial en menores: Riesgo social y trayectoria natural de desarrollo [Antisocial behavior in adolescents: Social risk and natural developmental trajectory]. Revista Mexicana de Psicología, 27(2), $127-142$. Retrieved https://www.redalyc.org/pdf/2430/243016324002.pdf

Arias, E., Arce, R., \& Vilariño, M. (2013). Batterer intervention programmes: A meta-analytic review of effectiveness. Psychosocial Intervention, 22(2), 153-160. http://dx.doi.org/10.5093/in2013a18

Babcock, J. C., Green, C. E., \& Robie, C. (2004). Does batterers' treatment work? A meta-analytic review of domestic violence treatment. Clinical Psychology Review, 23(8), 1023-1053. https://doi.org/10.1016/j.cpr.2002.07.001

Basanta, J., Fariña, F., \& Arce, R. (2018). Risk-Need-Responsivity Model: Contrasting criminogenic and noncriminogenic needs in high and low risk juvenile offenders. Children and Youth Services Review, 85, 137-142. https://doi.org/10.1016/j.childyouth.2017.12.024

Bonta, J., \& Andrews, D. A. (2017). The psychology of criminal conduct (6th ed.). New York, NY: Routledge.

Brackett, M. A., Rivers, S. E., \& Salovey, P. (2011). Emotional intelligence: Implications for personal, social, academic, and workplace success. Social and Personality Psychology Compass, 5(1), 88-103. https://doi.org/10.1111/j.1751-9004.2010.00334.x

Brazão, N., Rijo, D., Salvador, M. D. C., \& Pinto-Gouveia, J. (2017). The effects of the growing pro-social program on cognitive distortions and early maladaptive schemas over time in male prison inmates: A randomized controlled trial. Journal of Consulting and Clinical Psychology, 85(11), 1064. https://doi.org/10.1037/ccp0000247

Carbajosa, P., Catalá-Miñana, A., Lila, M., \& Gracia, E. (2017). Differences in treatment adherence, program completion, and recidivism among batterer subtypes. European Journal of Psychology Applied to Legal Context, 9(2), 93-101. https://doi.org/10.1016/j.ejpal.2017.04.001

Carbajosa, P., Catalá-Miñana, A., Lila, M., Gracia, E., \& Boira, S. (2017). Responsive versus treatment-resistant perpetrators in batterer intervention programs: Personal characteristics and stages of change. Psychiatry, Psychology and Law, 24(6), 936-950. https://doi.org/10.1080/13218719.2017.1347933

Fariña, F., Redondo, L., Seijo, D., Novo, M., \& Arce, R. (2017). A metaanalytic review of the MMPI validity scales and indexes to detect defensiveness in custody evaluations. International Journal of Clinical and Health Psychology, 17,

128-138. https://dx.doi.org/10.1016/j.ijchp.2017.02.002

Fernández-Berrocal, P., Extremera, N., \& Ramos, N. (2004). Validity and reliability of the Spanish modified version of the Trait Meta-Mood $\begin{array}{llll}\text { Scale. } & \text { Psychological } & \text { Reports, } & \text { 94(3), }\end{array}$ https://doi.org/10.2466/pr0.94.3.751-755

Fernández-Suárez, A., Pérez, B., Herrero, J. B., Juarros-Basterrechea, J., \& Rodríguez Díaz, F. J. (2018). The role of psychopathic traits among intimate partner-violent men: A systematic review. Revista Iberoamericana de Psicología y Salud, 94 https://doi.org/10.23923/j.rips.2018.02.017

Ferrando, P. J., Demestre, J., Anguiano-Carrasco, C., \& Chico, E. (2011). Evaluación TRI de la escala IE de Rotter: Un nuevo enfoque y algunas consideraciones [An IRT assessment of Rotter's I-E scale: A new approach and some considerations]. Psicothema, 23(2), 282-288. http://www.psicothema.com/psicothema.asp?id=3883

Finkenauer, C., Buyukcan-Tetik, A., Baumeister, R. F., Schoemaker, K., Bartels, M., \& Vohs, K. D. (2015). Out of control: Identifying the role of self-control strength in family violence. Current Directions in $\begin{array}{lll}\text { Psychological } & \text { Science, } & \text { 24(4), }\end{array}$ https://doi.org/10.1177/0963721415570730

Fitts, W. H., \& Warren, W. L. (1996). Tennessee self-concept scale: TSCS-2. Los Angeles, CA: Western Psychological Services.

Foran, H. M., \& O'Leary, K. D. (2008). Problem drinking, jealousy, and anger control: Variables predicting physical aggression against a partner. Journal of Family Violence, 23(3), 141-148. https://doi.org/10.1007/s10896-007-9136-5

Gannon, T. A., Olver, M. E., Mallion, J. S., \& James, M. (2019). Does specialized psychological treatment for offending reduce recidivism? A meta-analysis examining staff and program variables as predictors of treatment effectiveness. Clinical Psychology Review, 101752. https://doi.org/10.1016/j.cpr.2019.101752

Kirchner, T., Forns, M., Muñoz, D., \& Pereda, N. (2008). Psychometric properties and dimensional structure of the Spanish version of the Coping Responses Inventory Adult Form. Psicothema, 20(4), 902-909. Retrieved from http://www.psicothema.com/pdf/3573.pdf

Ley Orgánica 1/1979, de 26 de septiembre, General Penitenciaria. (1979). Boletin Oficial del Estado, 239, 23180-23186. Retrieved from https://www.boe.es/buscar/pdf/1979/BOE-A-1979-23708consolidado.pdf

Ley Orgánica 3/2018, de 5 de diciembre, de Protección de Datos Personales y Garantía de los Derechos Digitales (2018). Boletín Oficial del Estado, 294, 119788-119857. Retrieved from https://www.boe.es/boe/dias/2018/12/06/pdfs/BOE-A-201816673.pdf

Lila, M., Gracia, E., \& Catalá-Miñana, A. (2018). Individualized motivational plans in batterer intervention programs: A randomized clinical trial. Journal of Consulting and Clinical Psychology, 86(4), 309-320. https://doi.org/10.1037/ccp0000291

Lila, M., Martín-Fernández, M., Gracia, E., López-Ossorio, J. J., \& González, J. L. (2019). Identifying key predictors of recidivism among offenders attending a batterer intervention program: A survival analysis. Psychosocial Intervention, 28(3), 157-167. https://doi.org/10.5093/pi2019a19

Lila, M. Oliver, A., Catalá-Miñana, A., Galiana, L., \& Gracia, E. (2014). The intimate partner violence responsibility attribution scale (IPVRAS). European Journal of Psychology Applied to Legal Context, 6(1), 29-36. https://doi.org/10.5093/ejpalc2014a4

Loinaz, I., Marzabal, I., \& Andrés-Pueyo, A. (2018). Risk factors of female intimate partner and non-intimate partner homicides. European Journal of Psychology Applied to Legal Context, 10(2), 49-55. https://doi.org/10.5093/ejpalc2018a4

Martín, A. M., Padrón, F., \& Redondo, S. (2019). Early narratives of desistance from crime in different prison regimes. European Journal of Psychology Applied to Legal Context, 11(2), 71-79. https://doi.org/10.5093/ejpalc2019a2

Martín-Fernández, M., Gracia, E., \& Lila, M. (2018). Assessing victimblaming attitudes in cases of intimate partner violence against women: Development and validation of the VB-IPVAW scale. Psychosocial Intervention, 27(3), 133-143. https://doi.org/10.5093/pi2018a18

Martín-Fernández, M., Gracia, E., Marco, M., Vargas, V., Santirso, F. A., \& Lila, M. (2018). Measuring acceptability of intimate partner violence against women: Development and validation of the A-IPVAW scale. European Journal of Psychology Applied to Legal Context, 10(1), 26-34. https://doi.org/10.5093/ejpalc2018a3

Martinson, R. (1974). What works? Questions and answers about prison reform. The Public Interest, 10, 22-54.

Maruna, S. (2004). Desistance and explanatory style: A new direction in the psychology of reform. Journal of Contemporary Criminal Justice, 20, 184200. https://doi.org/10.1177/1043986204263778

Miguel-Tobal, J. J., Casado, M. I., Cano-Vindel, A., \& Spielberger, C. D. (2001). Inventario de expresión de ira estado-rasgo: STAXI-2. Madrid, Spain: TEA.

Monteiro, A., Vázquez, M. J., Seijo, D., \& Arce, R. (2018). ¿Son los criterios de realidad válidos para clasificar y discernir entre memorias de hechos auto-experimentados y de eventos vistos en vídeo? [Are the reality criteria valid to classify and to discriminate between memories of selfexperienced events and memories of video-observed events?] Revista Iberoamericana de Psicología y Salud, 9(2), 149-160. https://doi.org/10.23923/j.rips.2018.02.020

Podsakoff, P. M., MacKenzie, S. B., Lee, J.-Y., \& Podsakoff, N. P. (2003). Common method bias in behavioral research: A critical review of the literature and recommended remedies. Journal of Applied Psychology, 88(5), 879-903. http://dx.doi.org/10.1037/0021-9010.88.5.879

Ramiro-Sánchez, T., Ramiro, M. T., Bermúdez, M. P., \& Buela-Casal, G. (2018). Sexism in adolescent relationships: A systematic review. Psychosocial Intervention, 27(3), 123-132. https://doi.org/10.5093/pi2018a19

Redondo, L., Fariña, F., Seijo, D., Novo, M., \& Arce, R. (2019). A meta- 
analytical review of the responses in the MMPI-2/MMPI-2-RF clinical and restructured scales of parents in child custody dispute. Anales de Psicología, 35(1) 156-165. http://dx.doi.org/10.6018/analesps.35.1.338381

Redondo, S., Sánchez-Meca, J., \& Garrido, V. (2002). Los programas psicológicos con delincuentes y su efectividad: La situación europea Psychological programmes with offenders and their effectiveness: The European situation]. Psicothema, 14(Supl.), 164-173. Retrieved from http://www.psicothema.com/pdf/3487.pdf

Romero-Martínez, Á., Lila, M., Gracia, E., \& Moya-Albiol, L. (2019). Improving empathy with motivational strategies in batterer intervention programmes: Results of a randomized controlled trial. British Journal of Clinical Psychology, 58(2), 125-139. https://doi.org/10.1111/bjc.12204

Romero-Martínez, Á., Lila, M., Martínez, M., Pedrón-Rico, V., \& Moya-
Albiol, L. (2016). Improvements in empathy and cognitive flexibility after court-mandated intervention program in intimate partner violence perpetrators: The role of alcohol abuse. International Journal of Environmental Research and Public Health, 13(4), 394. https://doi.org/10.3390/ijerph13040394

Schmucker, M., \& Lösel, F. (2015). The effects of sexual offender treatment on recidivism: An international meta-analysis of sound quality evaluations. Journal of Experimental Criminology, 11, 597-630. http://dx.doi.org/10.1007/s11292-015-9241-z

Weber, E. N., Taylor, A. R., Cantos, A. L., Amado, B. G., \& O’Leary, K. D. (2019). Exploring typology categorizations of male perpetrators: A methodology study. European Journal of Psychology Applied to Legal Context, 11(2), 93-97. https://doi.org/10.5093/ejpalc2019a5 